\title{
Atom Transfer Radical Polymerization of Methacrylic Acid: A Won Challenge
}

Marco Fantin, ${ }^{\S, \dagger}$ Abdirisak A. Isse, ${ }^{\S} *$ Alfonso Venzo, ${ }^{\ddagger}$ Armando Gennaro, ${ }^{\S, *}$ and Krzysztof Matyjaszewski ${ }^{\dagger}, *$

${ }^{\S}$ Department of Chemical Sciences, University of Padova, Via Marzolo 1, 35131 Padova, Italy

${ }^{\dagger}$ Center for Molecular Engineering, Department of Chemistry, Carnegie Mellon University, 4400 Fifth Avenue, Pittsburgh, Pennsylvania 15213, United States

IENI - CNR, Department of Chemical Sciences, University of Padova, Via Marzolo 1, 35131 Padova, Italy

\section{Supporting Information}

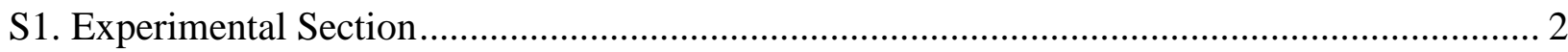

S2. Investigation of the Catalytic System in the presence of MAA .......................................... 4

Electrochemical analysis of the copper complex .......................................................... 4

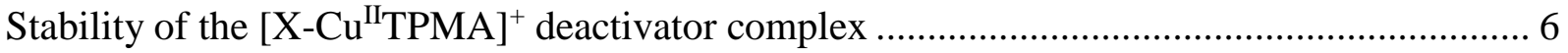

Evaluation of the Role of Radical-Radical Termination.................................................... 8

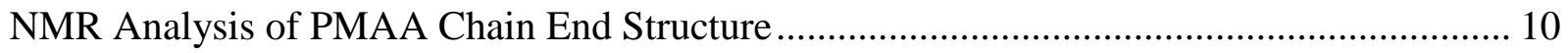

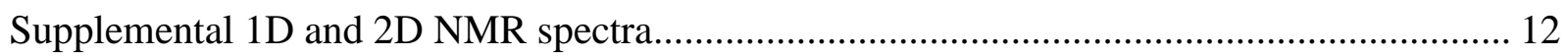

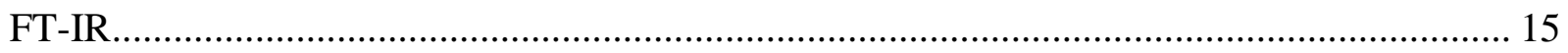

$\mathrm{S} 3$. Electrochemical characterization of $\mathrm{Cu} / \mathrm{TPMA}$ in the presence of MAA and $\mathrm{HCl}$.............. 15

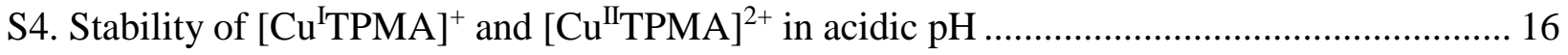

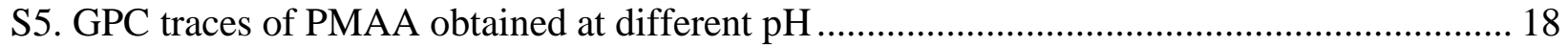

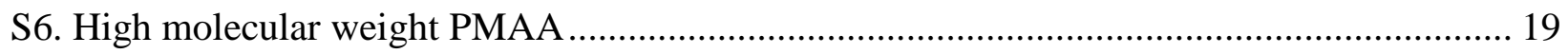

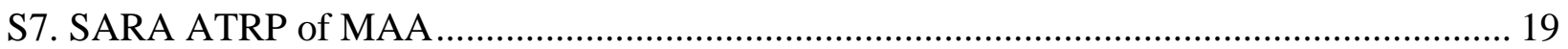

S8. ATRP of MAA at different monomer concentrations .................................................... 20

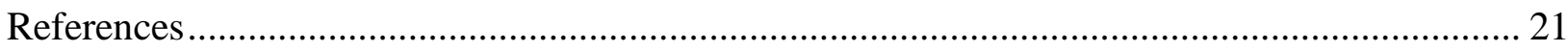




\section{S1. Experimental Section}

Chemicals. $\mathrm{CuCl}_{2}$ (Sigma-Aldrich, 99\%), $\mathrm{CuBr}_{2}$ (Sigma-Aldrich, 99\%), 2-hydroxyethyl 2-bromoisobutyrate (HEBiB, Sigma-Aldrich, 95\%), 2-bromoisobutyric acid (BiBA, Sigma-Aldrich, 98\%), $\alpha$-bromophenylacetic acid (BPAA, Sigma-Aldrich, 98\%), NaCl (Fisher Scientific, 99.0\%), $\mathrm{NaBr}$ (Fisher Scientific, 99.0\%), $\mathrm{Na}_{2} \mathrm{HPO}_{4}$ (Fisher Scientific, 99\%) and $37 \% \mathrm{HCl}$ aqueous solution (Fisher Scientific, ACS grade) were all used without purification. TPMA was synthetized according to a published procedure. ${ }^{1}$ Methacrylic acid (MAA, Sigma-Aldrich, $99 \%$ ) was distilled through a $10 \mathrm{~cm}$ Vigreux column to remove polymerization inhibitors. Copper wire (Alfa-Aesar, 99.9\%) was washed in $\mathrm{MeOH} / \mathrm{HCl}(3: 1, \mathrm{v} / \mathrm{v})$, then rinsed with $\mathrm{MeOH}$ and dried under nitrogen. Deionized water was further purified with a Barnstead Nanopure system (Thermo Scientific).

Instrumentation. Cyclic voltammetry (CV) and controlled-potential electrolysis were carried out on a Gamry Reference 600 potentiostat in a thermostated three-electrode cell under $\mathrm{N}_{2}$ atmosphere, using a Pt disk ( $3 \mathrm{~mm}$ diameter, Gamry) or Pt gauze (100 mesh, geometrical area $\sim 6 \mathrm{~cm}^{2}$, Alfa Aesar) as working electrodes. A saturated calomel electrode (SCE, Gamry) and a Pt plate were used as reference and counter electrodes, respectively. Prior to each experiment, the Pt disk was polished with a $0.25-\mu \mathrm{m}$ diamond paste and sonicated in ethanol for $5 \mathrm{~min}$.

${ }^{1} \mathrm{H}, 2 \mathrm{D}-\mathrm{COSY}, \mathrm{ROESY}, \mathrm{HSQC}$ and HMBC NMR of the SARA ATRP polymerization mixture experiments were obtained on a Bruker $500 \mathrm{MHz}$ spectrometer.

$K_{\mathrm{Cl}}$ determination. The equilibrium constant, $K_{\mathrm{Cl}}$, of association of chloride ions to [Cu ${ }^{\mathrm{II}} \mathrm{TPMA}$ ] was determined by Vis-NIR spectrophotometric titration of the copper complex with $\mathrm{Et}_{4} \mathrm{NCl}$. Spectra were recorded on a Cary 5000 spectrometer in a $1.00 \mathrm{~cm}$ quartz cuvette at $c a .25{ }^{\circ} \mathrm{C}$. A $3 \times 10^{-3} \mathrm{M} \mathrm{Cu}^{\mathrm{II}}(\mathrm{OTf})_{2} / \mathrm{TPMA}$ solution in $20 \% \mathrm{v} / \mathrm{v}$ MAA in water $+0.1 \mathrm{M} \mathrm{Et}_{4} \mathrm{NBF}_{4}$ was prepared in a cuvette $\left(V_{0}=2 \mathrm{~mL}\right)$, and a spectrum was recorded. Then, spectra were recorded after consecutive step-wise additions of a $20 \% \mathrm{v} / \mathrm{v}$ MAA in an aqueous solution containing $3 \times 10^{-3} \mathrm{M}$ $\mathrm{Cu}^{\mathrm{II}}(\mathrm{OTf})_{2} / \mathrm{TPMA}$ and $9.98 \times 10^{-2} \mathrm{M} \mathrm{Et}_{4} \mathrm{NCl}$.

First, we assumed that only two complexes were present in solution: $\left[\mathrm{Cu}^{\mathrm{II}} \mathrm{TPMA}\right]^{2+}$ and $\left[\mathrm{Cl}-\mathrm{Cu}^{\mathrm{II}} \mathrm{TPMA}\right]^{+}$. The presence of one isosbestic point (Figure S2) confirmed the presence of only two copper species.

At the beginning of the experiment, mixing $\mathrm{Cu}^{\mathrm{II}}(\mathrm{OTf})_{2}$ and TPMA generated only $\left[\mathrm{Cu}^{\mathrm{II}} \mathrm{T}\right.$ PMA $]^{2+}$, with a high formation constant $(\log K=17.6)^{2}$. TPMA essentially quantitatively bonded 
to $\mathrm{Cu}^{2+}$ even in the presence of MAA ( $\mathrm{pH} \sim 2$, see also Table $\mathrm{S} 1$ ). On the other hand, we neglected the association of the $\mathrm{OTf}^{-}$anion to copper. Solvent molecules that may be present in the $\mathrm{Cu}^{\mathrm{II}}$ coordination sphere were also omitted.

Titrating $\left[\mathrm{Cu}^{\mathrm{II}} \mathrm{TPMA}\right]^{2+}$ with $\mathrm{Et}_{4} \mathrm{NCl}$ (from 0 to $50 \mathrm{mM}$ ) generated $\left[\mathrm{Cl}-\mathrm{Cu}^{\mathrm{II}} \mathrm{TPMA}\right]^{+}$as the only species. The formation of $\mathrm{Cu}$ /TPMA complexes bearing more than one $\mathrm{Cl}^{-}$is unlikely in water, where halides bind weakly to $\mathrm{Cu}^{2+}$. Indeed, copper complexes with only one halide anion were reported for several other $\mathrm{Cu}^{2+}$-amine ligand systems in water. ${ }^{2-3}$

Recorded data were processed in an Excel spreadsheet, where the Generalized Reduced Gradient (GRG) nonlinear algorithm minimized the sum of the squared differences between experimental and calculated absorbance values. The program required the following inputs: the molar extinction coefficients of $\left[\mathrm{Cu}^{\mathrm{II}} \mathrm{TPMA}\right]^{2+}$ at three different wavelengths $\left(141 \mathrm{M}^{-1} \mathrm{~cm}^{-1} @ 790 \mathrm{~nm}\right.$, $158 \mathrm{M}^{-1} \mathrm{~cm}^{-1} @ 810,170 \mathrm{M}^{-1} \mathrm{~cm}^{-1} @ 830 \mathrm{~nm}$ ), absorbance values in the absence and presence of various amount of $\mathrm{Et}_{4} \mathrm{NCl}$ (from 0 to $42 \mathrm{mM}$ ), and the concentration of all introduced species. The program outputs were: the $\left[\mathrm{Cu}^{\mathrm{II}} \mathrm{TPMA}\right]^{2+}$ chloridophilicity constant $\left(K_{\mathrm{Cl}}=38 \mathrm{M}^{-1}\right)$, the molar extinction coefficient of $\left[\mathrm{Cl}-\mathrm{Cu}{ }^{\mathrm{II}} \mathrm{TPMA}\right]^{+}$at each of the three selected wavelengths $\left(81 \mathrm{M}^{-1} \mathrm{~cm}^{-1}\right.$ @790 nm, $\left.95 \mathrm{M}^{-1} \mathrm{~cm}^{-1} @ 810 \mathrm{~nm}, 111 \mathrm{M}^{-1} \mathrm{~cm}^{-1} @ 830 \mathrm{~nm}\right)$, a fitting of the calculated absorbance data on the experimental ones (Figure S2b), and the squared sum of the differences between calculated and experimental absorbance values. From the last output, we determined that the average difference between experimental and calculated values was small (0.0003 absorbance units).

General $\boldsymbol{e A T R P}$ procedure. A seven-necked, thermostated electrochemical cell was used for the polymerizations. In a typical experiment, $0.200 \mathrm{~g}$ of $\mathrm{NaCl}\left(3.42 \times 10^{-3} \mathrm{~mol}\right), 2.0 \mathrm{~mL}$ of MAA (2.03 g, $0.0236 \mathrm{~mol}), 0.236 \mathrm{~mL}$ of a $0.05 \mathrm{M} \mathrm{CuCl}_{2} /$ TPMA stock solution $\left(1.18 \times 10^{-5} \mathrm{~mol} \mathrm{Cu}\right), 1.18 \mathrm{~mL}$ of a $0.100 \mathrm{M}$ BiBA solution $\left(1.18 \times 10^{-4} \mathrm{~mol}\right)$, and $2.1 \mathrm{~mL}$ of a $1.2 \mathrm{M} \mathrm{HCl}$ solution $\left(2.52 \times 10^{-3} \mathrm{~mol}\right.$ $\mathrm{HCl}$ ) were added to $14.5 \mathrm{~mL}$ of $\mathrm{H}_{2} \mathrm{O}$. The electrolysis experiments were carried out in a divided cell, using a glass frit and a salt bridge made of methylcellulose gel saturated with $\mathrm{Et}_{4} \mathrm{NBF}_{4}$ to separate the cathodic and anodic compartments. During electrolysis, the cathodic compartment was maintained under vigorous magnetic stirring. All experiments were performed at $25^{\circ} \mathrm{C}$. The Pt gauze was activated in $0.1 \mathrm{M} \mathrm{H}_{2} \mathrm{SO}_{4}$ with cyclic anodic/cathodic steps of 6 seconds with a current density of $\sim 30 \mathrm{~mA} / \mathrm{cm}^{2}$, for a total time of $30 \mathrm{~min}$. The working solution was bubbled with $\mathrm{N}_{2}$ for 30 min. 
Monomer conversions were measured by ${ }^{1} \mathrm{H}$ NMR analysis in $\mathrm{D}_{2} \mathrm{O}$ using a Bruker $300 \mathrm{MHz}$ spectrometer. Theoretical molecular weight was calculated as $M_{\mathrm{n}, \mathrm{th}}=M M_{\mathrm{RX}}+$ $M M_{\mathrm{MAA}} \times\left(C_{\mathrm{MAA}} / C_{\mathrm{RX}}\right) \times$ conversion. Molecular weight $\left(M_{\mathrm{n}, \mathrm{app}}\right)$ and dispersity $\left(D, M_{\mathrm{w}} / M_{\mathrm{n}}\right)$ values were determined by aqueous gel-permeation chromatography (GPC), using a Waters RI detector and PSS columns with a calibration based on PSS poly(sodium methacrylate) standards (in $0.1 \mathrm{M}$ $\mathrm{Na}_{2} \mathrm{HPO}_{4}$ at $\left.30{ }^{\circ} \mathrm{C}\right) .{ }^{4} M_{\mathrm{n} \text {,app }}$ was corrected considering the molecular weight difference between poly(sodium methacrylate), present in the liquid GPC phase at $\mathrm{pH}$ 9, and poly(methacrylic acid) present in the reaction environment. Before the analysis, the polymer samples were passed through a PES filter.

General SARA ATRP procedure. $0.5 \mathrm{~mL}$ of MAA $\left(0.508 \mathrm{~g}, 5.9 \times 10^{-3} \mathrm{~mol}\right), 3.5 \mathrm{mg}$ TPMA $\left(1.2 \times 10^{-5} \mathrm{~mol}\right), 5.9 \mu \mathrm{L}$ of a $0.05 \mathrm{M} \mathrm{CuCl}_{2}$ stock solution $\left(2.95 \times 10^{-7} \mathrm{~mol} \mathrm{Cu}\right), 0.295 \mathrm{~mL}$ of a 0.100 M BiBA solution $\left(2.95 \times 10^{-5} \mathrm{~mol}\right)$, and $0.525 \mathrm{~mL}$ of a $1.2 \mathrm{M} \mathrm{HCl}$ solution $\left(6.3 \times 10^{-4} \mathrm{~mol}\right)$ were added to $3.75 \mathrm{~mL}$ of $\mathrm{H}_{2} \mathrm{O}$. The solution was degassed for at least $30 \mathrm{~min}$ and then transferred to a previously degassed and sealed flask containing a $10 \mathrm{~cm} \mathrm{Cu}$ wire with diameter $d=1 \mathrm{~mm}$. Unless otherwise stated in the manuscript, the copper wire was activated with $\mathrm{MeOH} /$ aqueous $\mathrm{HCl}$ (3:1, $\mathrm{v} / \mathrm{v})$, rinsed with $\mathrm{MeOH}$ and dried under $\mathrm{N}_{2}$.

\section{S2. Investigation of the Catalytic System in the presence of MAA}

\section{Electrochemical analysis of the copper complex}

Cyclic voltammetry of $\left[\mathrm{Cu}^{\mathrm{II}} \mathrm{TPMA}\right]^{2+}$ in $10 \% \mathrm{v} / \mathrm{v}$ MAA in water $+0.1 \mathrm{M} \mathrm{NaBr}$ exhibits a reversible peak couple with $E^{\ominus}=-0.20 \mathrm{~V}$ vs. SCE (blue line in Figure S1a). $E^{\ominus}$ was obtained as the midpoint between the cathodic, $E_{\mathrm{pc}}$, and anodic, $E_{\mathrm{pa}}$, peak potentials, $\left(E_{\mathrm{pc}}+E_{\mathrm{pa}}\right) / 2=E_{1 / 2} \approx E^{\ominus}$. For comparison, $E^{\ominus}$ of $\left[\mathrm{Cu}^{\mathrm{II}} \mathrm{TPMA}\right]^{2+}$ in $10 \% \mathrm{v} / \mathrm{v}$ OEOMA in water $+0.1 \mathrm{M} \mathrm{Et}_{4} \mathrm{NBr}$ is $-0.26 \mathrm{~V}$ vs. SCE. ${ }^{3}$ This difference in the redox potentials $(0.06 \mathrm{~V})$ suggests that the complex is a slightly less active and weaker reducing agent in the presence of MAA than in the presence of OEOMA. Nevertheless, it is important to note that such a small decrease in activity of the catalyst cannot be considered responsible for the observed failure of MAA polymerization. Indeed, $E^{\ominus}$ of the catalyst in $10 \% \mathrm{v} / \mathrm{v}$ MAA in $\mathrm{H}_{2} \mathrm{O}$ is still very negative, indicating that the $\mathrm{Cu}$ complex should possess a suitable catalytic activity. 


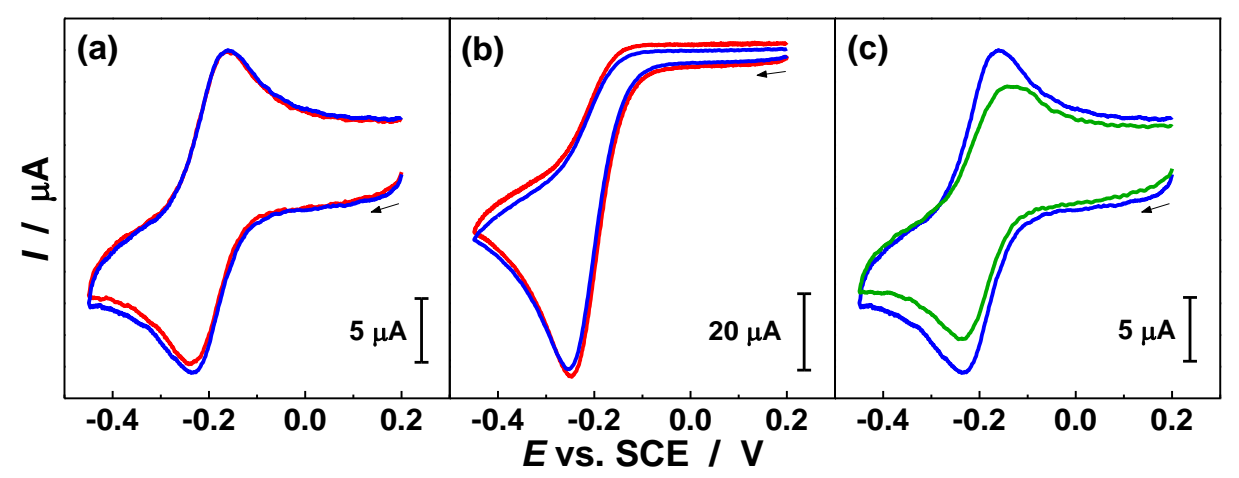

Figure S1. CV of $10^{-3} \mathrm{M}\left[\mathrm{Cu}^{\mathrm{II}} \mathrm{TPMA}\right]^{2+}$ in $10 \%$ v/v MAA in water $+0.1 \mathrm{M} \mathrm{NaBr}$ (a) in the absence and (b) in the presence of $5 \times 10^{-3} \mathrm{HEBiB}$. CV were recorded immediately after addition of the reagents (blue line) or after two hours of stirring (red line). (c) $\mathrm{CV}$ of $10^{-3} \mathrm{M}\left[\mathrm{Cu}^{\mathrm{II}} \mathrm{TPMA}\right]^{2+}$ in $10 \%$ $\mathrm{v} / \mathrm{v} \mathrm{MAA}$ in water $+0.1 \mathrm{M} \mathrm{NaBr}$ in the absence of HEBiB (blue line), and in the presence of HEBiB after application of $E_{\text {app }}=-0.18 \mathrm{~V}$ vs. SCE for $2.5 \mathrm{~h}$, which triggered the polymerization of MAA oligomers (green line).

To study the longtime stability of $\left[\mathrm{Cu}^{\mathrm{II}} \mathrm{TPMA}\right]^{+}$, the typical conditions of a polymerization experiment were simulated by preparing a cell with all components needed for $e$ ATRP and leaving it under intense stirring for $2 \mathrm{~h}$ without any applied potential. The $\mathrm{CV}$ recorded after $2 \mathrm{~h}$ is reported in Figure S1a (red line). The shape of the voltammetric curve of $\left[\mathrm{Cu}^{\mathrm{II}} \mathrm{TPMA}\right]^{2+}$ was unchanged and since no other peaks appeared in the $\mathrm{CV}$, it was concluded that the initial complex did not dissociate or react with MAA in competition with the ligand TPMA.

A similar situation was observed in the presence of the initiator HEBiB (Figure S1b). As expected, in this case, the CV was irreversible, confirming the catalytic behavior of the system. According to the catalytic cycle in Scheme $\mathrm{S} 1$, the electrogenerated $\left[\mathrm{Cu}{ }^{\mathrm{I}}\right]^{+}$quickly disappeared by reaction with the initiator, $\mathrm{RX}$. This reaction generated $\mathrm{Cu}^{\mathrm{II}}$ complexes and propagating radicals $\mathrm{R}^{\bullet}$, which after adding to a few monomer units converted back to a dormant state, regenerating $\mathrm{Cu}^{\mathrm{I}}$, or terminated leaving behind a $\mathrm{Cu}^{\mathrm{II}}$ complex. The $\mathrm{Cu}^{\mathrm{II}}$ species regenerated in the radical termination reactions were reduced at the working electrode, causing an increase in the cathodic current $\left(I_{\mathrm{pc}}\right)$. The faster $\left[\mathrm{Cu}^{\mathrm{I} L}\right]^{+}$reacts with $\mathrm{RX}$, the greater the concentration of $\mathrm{R}^{\bullet}$ and the faster the termination reactions. Consequently, the catalytic current enhancement strongly depends on the activation rate. The reduction step may involve either $\left[\mathrm{X}-\mathrm{Cu}{ }^{\mathrm{II}} \mathrm{L}\right]^{+}$or $\left[\mathrm{Cu}^{\mathrm{II}} \mathrm{L}\right]^{2+}$ formed after disso- 
ciation of the ternary complex (in water, $\left[\mathrm{X}-\mathrm{Cu}^{\mathrm{II}} \mathrm{L}\right]^{+}$and $\left[\mathrm{Cu}{ }^{\mathrm{II}} \mathrm{L}\right]^{+}$have similar reduction potentials). ${ }^{3}$ As in the previous case, the voltammetric pattern was essentially unchanged after two hours of stirring in the presence of MAA. This test indicated that the initiator was stable and did not hydrolyze, while the activity of the catalyst was maintained.

\section{Scheme S1. Catalytic Cycle Involving Radical-Radical Termination and Heterogeneous Elec- tron Transfer to $\mathrm{Cu}^{\mathrm{II}}$}
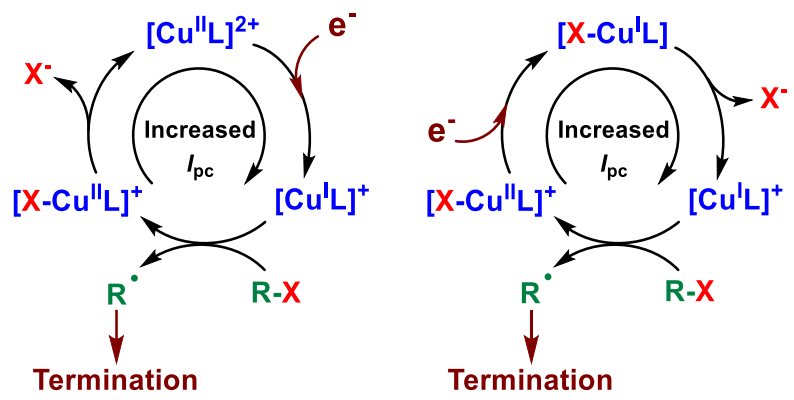

In the presence of PMAA oligomers, obtained from $e$ ATRP under standard aqueous conditions (7\% of MAA conversion), a reversible peak couple corresponding to the original [Cu $\left.{ }^{\mathrm{II}} \mathrm{TPMA}\right]^{2+}$ was observed in cyclic voltammetry (Figure S1c). This proved that the complex was stable also in the presence of PMAA, which could act as a stronger polydentate ligand, involving multiple carboxylic groups to bind $\mathrm{Cu}^{\mathrm{II}}$ ions. On the other hand, the absence of any catalytic current implied the absence of active $\mathrm{C}$ - $\mathrm{Br}$ bonds. The small decrease in the intensity of the $\mathrm{CV}$ can be accounted for by an increase of solution viscosity due to the production of poly(methacrylic acid). It is, however, clear that the copper complex is still present in solution in its original form, i.e., $\left[\mathrm{Cu}^{\mathrm{II}} \mathrm{T}\right.$ $\mathrm{PMA}]^{+}$: no significant change on $\mathrm{CV}$ shape and, above all, the same $E_{1 / 2}$ of the original complex.

\section{Stability of the [X-CuITPMA $]^{+}$deactivator complex}

In contrast to organic solvents, in which halide anions bind strongly to $\mathrm{Cu}^{\mathrm{II}}$-amine ligands, ${ }^{5}$ in pure water the equilibrium constant, $K_{\mathrm{x}}$, of reaction $\mathrm{S} 1$ is much lower, which is one of the biggest problems in controlling ATRP in aqueous media. ${ }^{3}$

$$
\left[\mathrm{Cu}{ }^{\mathrm{II}} \mathrm{TPMA}\right]^{2+}+\mathrm{X}^{-} \stackrel{K_{\mathrm{X}}}{\rightleftarrows}\left[\mathrm{X}-\mathrm{Cu}{ }^{\mathrm{II}} \mathrm{TPMA}\right]^{+}
$$


The equilibrium constant of reaction $\mathrm{S} 1$ for $\mathrm{X}=\mathrm{Cl}$ was determined by spectrophotometric titration in $20 \% \mathrm{v} / \mathrm{v}$ MAA in water at $0.1 \mathrm{M}$ ionic strength. Figure $\mathrm{S} 2$ shows Vis-NIR spectra of the system together with analysis of data at different wavelengths to extract $K_{\mathrm{Cl}}$. The presence of an isosbestic point at $922 \mathrm{~nm}$ (Figure S2) strongly suggested the presence of two well-defined species in solution, i.e. $\left[\mathrm{Cu}^{\mathrm{II}} \mathrm{L}\right]^{2+}$ and $\left[\mathrm{Cl}-\mathrm{Cu}{ }^{\mathrm{II}} \mathrm{L}\right]^{+}$.

The obtained value, $K_{\mathrm{Cl}}=38 \mathrm{M}^{-1}$, was higher than the value in pure water $\left(K_{\mathrm{Cl}}=9 \mathrm{M}^{-1}\right),{ }^{3}$ clearly indicating that the monomer does not compete with the halide ions. Instead, MAA acted as an organic solvent, reducing the polarity of the environment and facilitating the formation of the ternary $\left[\mathrm{X}-\mathrm{Cu}{ }^{\mathrm{II}} \mathrm{TPMA}\right]^{+}$deactivator complex. A similar behavior was observed for the addition of $\mathrm{MeOH}$ to water. ${ }^{6}$

Conversely, it was reported that carboxylic acids compete with the halide ions in the presence of organic solvents. ${ }^{7}$ Acetic acid partially displaced $\mathrm{Br}^{-}$from $\left[\mathrm{Br}-\mathrm{Cu}^{\mathrm{II}}(\mathrm{bpy})_{2}\right]^{+}$in a 75/25 ethanol/water (v/v) solution, where $K_{\mathrm{Br}}$ was halved (from $620 \mathrm{M}^{-1}$ to $302 \mathrm{M}^{-1}$ ) by addition of a small amount of acid $(2 \% \mathrm{v} / \mathrm{v})$. In pure water, the carboxylic function is better solvated than in organic solvent/water mixtures. In particular, in the case under investigation, no specific interaction between MAA and copper was observed in $20 \% \mathrm{v} / \mathrm{v}$ MAA in water.

Chloridophilicity in the presence of methacrylic acid is low, $K_{\mathrm{Cl}}=38 \mathrm{M}^{-1}$ (although 4 times higher than $K_{\mathrm{Cl}}$ in pure water). Thus, an excess of halide ions was required to prevent dissociation of the ternary deactivator complex $\left[\mathrm{X}-\mathrm{Cu}{ }^{\mathrm{II}} \mathrm{L}\right]^{+}$. Considering $\left.K_{\mathrm{Cl}}=38 \mathrm{M}^{-1}, C_{\left[\mathrm{Cu}^{\mathrm{II}} \mathrm{TPMA}\right.}\right]^{2+}=5.9 \times 10^{-4}$ $\mathrm{M}$, and $C_{\mathrm{Cl}^{-}}=0.1 \mathrm{M}, 79 \%$ of the $\mathrm{Cu}$ il is present in the form of the effective deactivator $\left[\mathrm{X}-\mathrm{Cu}^{\mathrm{II}} \mathrm{L}\right]^{+}$.
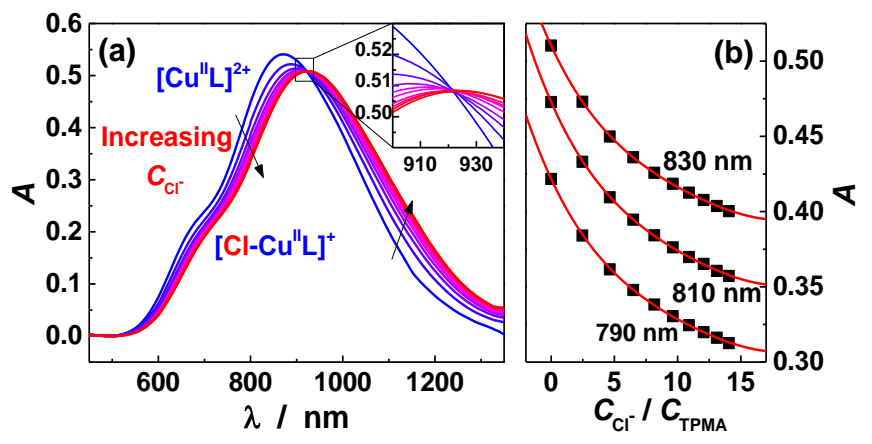

Figure S2. (a) Vis-NIR spectra of $3 \times 10^{-3} \mathrm{M} \mathrm{Cu}^{\mathrm{II}}(\mathrm{OTf})_{2} / \mathrm{TPMA}$ solutions at $25^{\circ} \mathrm{C}$ in $20 \% \mathrm{v} / \mathrm{v}$ MAA in water $+0.1 \mathrm{M} \mathrm{Et}_{4} \mathrm{NBF}_{4}, V_{0}=2 \mathrm{~mL}, C_{0}=3 \times 10^{-3} \mathrm{M}$; step additions ( 0 to $1.5 \mathrm{~mL}$ ) of a $20 \% \mathrm{v} / \mathrm{v}$ MAA aqueous solution containing $3 \times 10^{-3} \mathrm{M} \mathrm{Cu}^{\mathrm{II}}(\mathrm{OTf})_{2} / \mathrm{TPMA}$ and $9.98 \times 10^{-2} \mathrm{M} \mathrm{Et}_{4} \mathrm{NCl}$. (b) $\mathrm{Ab}-$ sorbance values at three selected wavelengths and best-fit curves. 


\section{Evaluation of the Role of Radical-Radical Termination}

Having proved the stability of both catalyst and initiator, the stability of the growing polymer was then studied. In principle, excessive radical-radical termination could be the cause of low conversion and lack of control. Electrochemically mediated ATRP allows a unique insight into radical chain-termination reactions: Scheme $\mathrm{S} 1$ highlights that one $\mathrm{Cu}^{\mathrm{II}}$ complex should be formed for each terminated radical. To allow the further activation of $\mathrm{C}-\mathrm{Br}$ bonds, $\mathrm{Cu}{ }^{\mathrm{II}}$ species must be reduced back to $\mathrm{Cu}^{\mathrm{I}}$ at the working electrode. Therefore, each termination event is accompanied by the successive one-electron reduction of a $\mathrm{Cu}^{\mathrm{II}}$ complex, with the consumption of one elementary charge. By recording the total consumed charge during an $e$ ATRP experiment, the number of active chains lost by radical-radical termination could be evaluated using equation S2 (the chronoamperometry curve used for the determination of the consumed charge is reported in Figure S3). Considering that at the beginning of the experiment, copper is present as $\mathrm{Cu}^{\mathrm{II}}$, the total measured charge $Q$ is the sum of two contributions: $Q_{0}$ for the initial reduction of $\mathrm{Cu}^{\mathrm{II}}$ species to $\mathrm{Cu}^{\mathrm{I}}$, and $Q_{\mathrm{R}}$ due to the reduction of $\mathrm{Cu}^{\mathrm{II}}$ species accumulated due to the radical-radical termination reactions.

$$
Q=Q_{0}+Q_{\mathrm{R}}=-\left(n_{0}+n_{\mathrm{R}}\right) F
$$

where $n_{0}$ is the number of moles of $\mathrm{Cu}^{\mathrm{II}}$ species initially converted to $\mathrm{Cu}^{\mathrm{I}}, n_{\mathrm{R}}$ is the number of moles of chain terminated by radical-radical reactions, and $F$ is the Faraday constant. $n_{0}$ was estimated by using the Nernst equation, neglecting the small overpotential related to the passage of current. The ratio between the concentrations of $\mathrm{Cu}^{\mathrm{I}}$ and $\mathrm{Cu}^{\mathrm{II}}$ can be expressed as:

$$
E_{\mathrm{app}} \approx E^{\mathrm{o} \prime}-\frac{R T}{F} \ln \frac{C_{\mathrm{Cu}^{\mathrm{I}}}}{C_{\mathrm{Cu}}{ }^{\mathrm{II}}}
$$

At $E_{\text {app }}=E^{\mathrm{o} \prime} \approx E_{1 / 2}=-0.20 \mathrm{~V}$, the $C_{\mathrm{Cu}^{\mathrm{I}}} / C_{\mathrm{Cu}^{\mathrm{II}}}$ ratio at the electrode is $\sim 1$, therefore half of the $\mathrm{Cu}^{\mathrm{II}}$ species are converted to $\mathrm{Cu}^{\mathrm{I}}$. This corresponds to $n_{0}=5.9 \times 10^{-6} \mathrm{~mol}$ and $Q_{0}=0.57 \mathrm{C}$. Subtracting this value from the measured $Q$ of $1.6 \mathrm{C}$ leaves $Q_{\mathrm{R}}=1.13 \mathrm{C}$; it follows that $n_{\mathrm{R}}=1.1 \times 10^{-5}$ mol. The number of growing chains is equal to the number of moles of initiator, $n_{\mathrm{RX}}=1.2 \times 10^{-4}$ mol. Therefore, the fraction of radical-radical terminated chains, $n_{\mathrm{R}} / n_{\mathrm{RX}}$, was only $9 \%$ of the total number of chains. Such a value is compatible with a controlled radical polymerization. ${ }^{8}$ Actually, the fraction of radical-radical terminated chain is $\leq 9 \%$, because the measured charge $Q$ might 
contain minor contributions from reduction of oxygen or other impurities, or reduction of $\mathrm{H}^{+}$to hydrogen. Therefore, most of the chain end functionality was not lost through radical-radical termination, but rather through a different pathway.

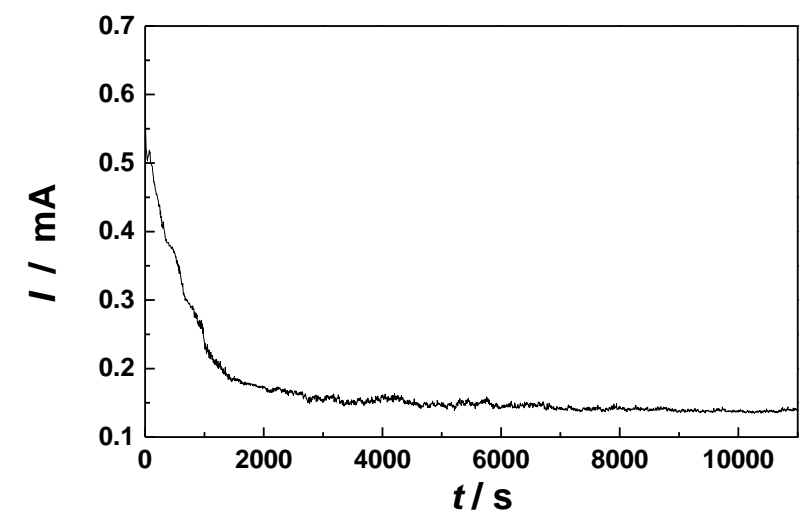

Figure S3. Chronoamperometry recorded during eATRP of $10 \% \mathrm{v} / \mathrm{v} \mathrm{MAA}$ in water $+0.1 \mathrm{M} \mathrm{NaBr}$ at $E_{\text {app }}=-0.20$ V vs. SCE. Conditions: [MAA]:[HEBiB]:[Cu(OTf) 2$]:[T P M A]=200: 1: 0.1: 0.1$. Total consumed charge $(Q=1.6 \mathrm{C})$ was calculated as the area under the curve.

Scheme S2. PMAA Cyclization and Structures of Other Relevant Chain Ends; $R=$ H or Oligomer Chain

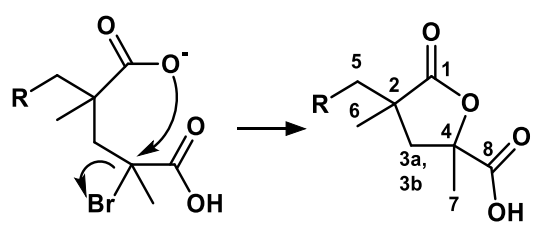

Active chain end

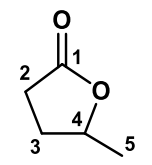

(C) $\gamma$-valerolactone
(A) Lactone

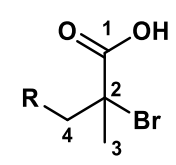

(D) Active chain end

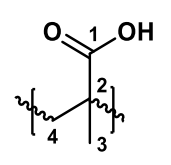

(B) Bulk polymer chain

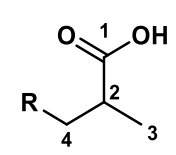

(E) Terminated chain

The mechanism of cyclization of the chain end resembles a $\mathrm{S}_{\mathrm{N}} 2$ mechanism (Scheme $\mathrm{S} 2$ ), but is strongly favored by the presence of $\mathrm{Cu}^{\mathrm{I}}$ and slows down by oxidation of $\mathrm{Cu}^{\mathrm{I}}$ to $\mathrm{Cu}^{\mathrm{II}}$. The exact mechanism is being investigated. 


\section{NMR Analysis of PMAA Chain End Structure}

To more precisely analyze the retained chain end via NMR spectroscopy, a synthesis of PMAA with a low degree of polymerization (DP) was carried out by SARA ATRP $\left(C_{\mathrm{M}}: C_{\mathrm{RX}}: C_{\mathrm{Cu}(\mathrm{OTf})_{2}}\right.$ : $C_{\mathrm{TPMA}}: C_{\mathrm{NaBr}}=10: 1: 0.001: 0.03: 5$, in $5 \%$ v/v MAA in $\mathrm{D}_{2} \mathrm{O}$, total $V=5 \mathrm{~mL}, 10 \mathrm{~cm} \mathrm{Cu}$ wire with diameter $d=1 \mathrm{~mm}, \mathrm{RX}=\alpha$-bromoisobutyric acid). Under such conditions, the reaction was fast, reaching $90 \%$ conversion in $1.5 \mathrm{~h}$. After this time, the reaction stopped, suggesting the loss of active $\mathrm{C}-\mathrm{Br}$ chain end functionality.

The ${ }^{1} \mathrm{H}-\mathrm{NMR}$ and 2D-Heteronuclear Multiple Bond Coherence (HMBC) spectra of the polymerization mixture (Figure S4) show the presence of a lactone (structure $\mathbf{A}$ in Scheme S2). First, the broad signals in the proton spectrum, centered at $\delta\left({ }^{1} \mathrm{H}\right)=1.05$ and $1.95 \mathrm{ppm}$, were assigned to the protons 3 and 4, respectively, of the bulk polymer chain (structure $\mathbf{B}$ ). In structure $\mathbf{A}$, protons $3 \mathrm{a}$ and $3 \mathrm{~b}$ have different chemical shifts $\left(\delta\left({ }^{1} \mathrm{H}\right)=2.60\right.$ and $\left.2.21 \mathrm{ppm}\right)$ with a coupling constant $J$, representing an $\mathrm{AB}$ system, typical of a cyclic structure ( $\mathrm{AB}$ quartet, $2 \mathrm{H}, J_{\mathrm{AB}}=13.9$ $\mathrm{Hz}$ ). Relevant chemical shift assignments are reported in Figure S4. The HMBC spectrum showed that protons $3 \mathrm{a}$ and $3 \mathrm{~b}$ correlated to carbons 1, 2, 3, 4, 5, 7 and 8, from which they were separated by a distance of 2-3 bonds. Protons 7 correlated to carbons 3,4 and 8 . The signal at $\delta\left({ }^{13} \mathrm{C}\right)=82.3$ ppm, was unambiguously assigned to the lactone quaternary carbon (carbon 4 of structure A), by analogy with the ${ }^{13} \mathrm{C}$ NMR spectrum of $\gamma$-valerolactone (carbon 4 of structure $\mathbf{C}, \delta\left({ }^{13} \mathrm{C}\right)=77.3$ ppm). ${ }^{9}$ Scheme $\mathbf{S} 2$ displays two chain end configurations (structures $\mathbf{D}$ and $\mathbf{E}$ ) typical of a polymer obtained by ATRP. Neither of these structures was compatible with the signal at $\delta\left({ }^{13} \mathrm{C}\right)=82.3$ ppm. Carbon 2 of the active chain end (Structure D) should have a chemical shift in the interval $55 \mathrm{ppm}<\delta\left({ }^{13} \mathrm{C}\right)<70 \mathrm{ppm},{ }^{10}$ in agreement with the spectrum of $\alpha$-bromoisobutyric acid (BiBA).${ }^{11}$ Radical-radical termination by disproportionation, on the other hand, would produce a tertiary carbon atom with $\delta\left({ }^{13} \mathrm{C}\right)<50$ ppm as a chain end (carbon 2 in structure $\mathbf{E}$ ). 


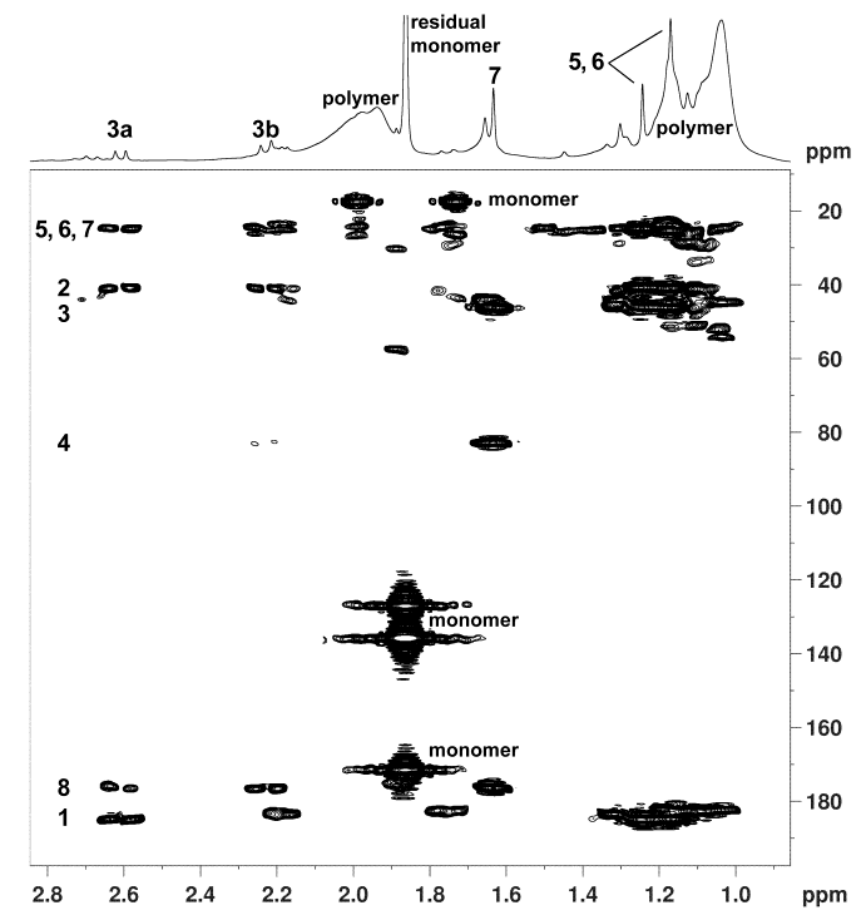

Figure S4. HMBC of the products of a SARA ATRP of MAA with target DP $=10$ in $\mathrm{D}_{2} \mathrm{O}$. Relevant atoms are labeled in agreement with structure $\mathbf{A}$ in Scheme $S 2$ (with $R=H$ ).

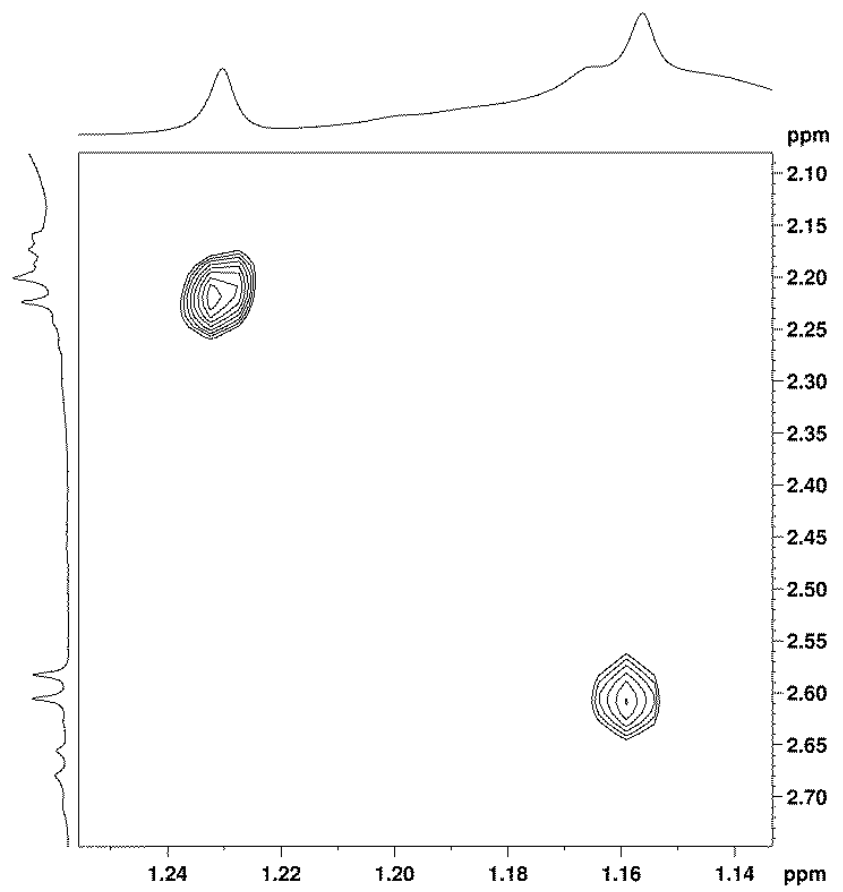

Figure S5. Details of ROESY spectrum of product mixture from the SARA ATRP of MAA with target $\mathrm{DP}=10$. 
Additionally, connectivity in the ROESY spectrum (Figure S5) suggested the presence of a lactone. The two doublets at $\delta=2.60$ and $\delta=2.21 \mathrm{ppm}$ (f1 axis), were attributed to the two protons in position 3 in structure $\mathbf{A}$, for their shape and their coupling constant ${ }^{3} J(\mathrm{H}, \mathrm{H})=13.9 \mathrm{~Hz}$. In the ROESY spectrum, they correlated (therefore they were "close" in space, below $4 \AA$ ) to the singlets at $\delta\left({ }^{1} \mathrm{H}\right)=1.16 \mathrm{ppm}\left[\delta\left({ }^{13} \mathrm{C}\right)=24.6 \mathrm{ppm}\right]$ and $\delta\left({ }^{1} \mathrm{H}\right)=1.24 \mathrm{ppm}\left[\delta\left({ }^{13} \mathrm{C}\right)=24.7 \mathrm{ppm}\right]$, respectively. From their shape and chemical shifts, the two singlets were attributed to $\mathrm{C} 5$ and $\mathrm{C} 6$ (with $\mathrm{R}=\mathrm{H}$ ). Each of the two methylene protons in 3 was "close" only to the protons of one methyl groups (C5 or C6). This situation is possible only in a well-defined cyclic structure (lactone $\mathbf{A}$ ) and not in an open structure (B or $\mathbf{C}$ ). In fact, the rotation around sigma bonds in an open structure would put both methylene protons close to both methyl groups (C5 and C6), resulting in cross ROESY correlations.

\section{Supplemental 1D and 2D NMR spectra}

${ }^{1} \mathrm{H}$ NMR and other relevant 2D NMR spectra are shown in Figures S6-8. A close inspection of these data shows several slightly different $\mathrm{AB}$ systems, indicating the presence of multiple slightly different lactone structures. At least three different AX systems are present:

- $\quad \delta 2.60$ and $\delta 2.21,\left(\mathrm{AB}\right.$ quartet, $\left.2 \mathrm{H}, J_{\mathrm{AB}}=13.9 \mathrm{~Hz}\right)$

- $\delta 2.68$ and $\delta 2.21\left(\mathrm{AB}\right.$ quartet, $\left.2 \mathrm{H}, \mathrm{J}_{\mathrm{AB}}=14.4 \mathrm{~Hz}\right)$

- $\delta 2.72$ and $\delta 2.20\left(\mathrm{AB}\right.$ quartet, $\left.2 \mathrm{H}, \mathrm{J}_{\mathrm{AB}}=15.2 \mathrm{~Hz}\right)$

These signals were attributable to a lactone structure (A) at the chain end of polymers with variable chain length. In any case, the $\mathrm{AB}$ system characterized by the two distorted doublets at $\delta=2.60$ and $\delta=2.21$ (Figure S7) represents the most relevant structure (structure A, with $\mathrm{R}=\mathrm{H}$ ). This suggested that, in the particular conditions of the previously described SARA ATRP experiment, most of the cyclization reaction occurred immediately after the first monomer addition to the initiator $\mathrm{BiBA}$, and therefore polymerization became hampered mainly at the beginning of the reaction, with concentration of structure $\mathbf{A}$ slowly increasing over time during polymerization (Figure S9). No signals attributable to the active $\mathrm{C}-\mathrm{Br}$ chain end were detected. 


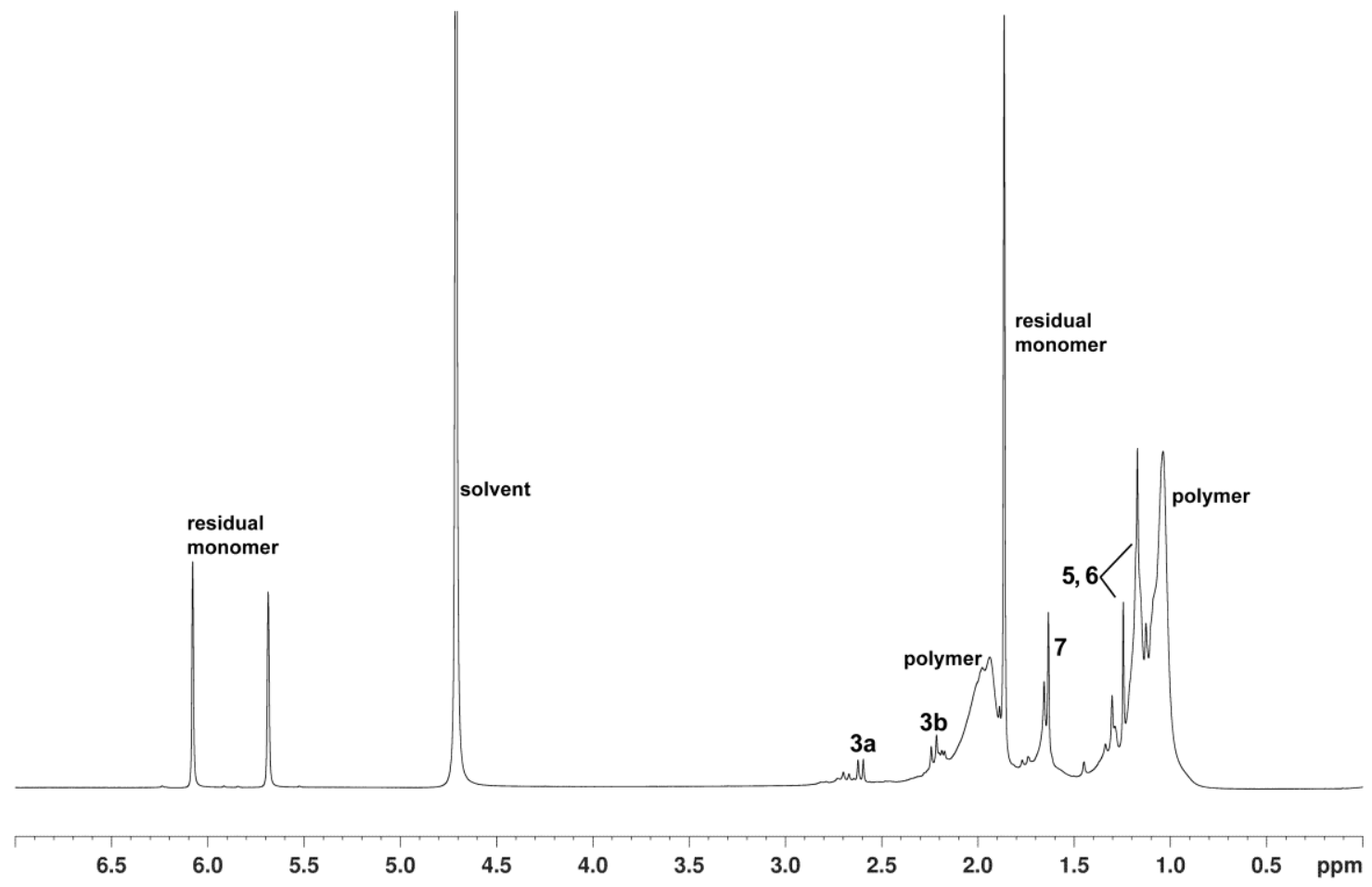

Figure S6. $600 \mathrm{MHz}{ }^{1} \mathrm{H}$ NMR of SARA ATRP mixture. Relevant atoms are labeled according to Structure A in Scheme S2 (with $\mathrm{R}=\mathrm{H}$ ).

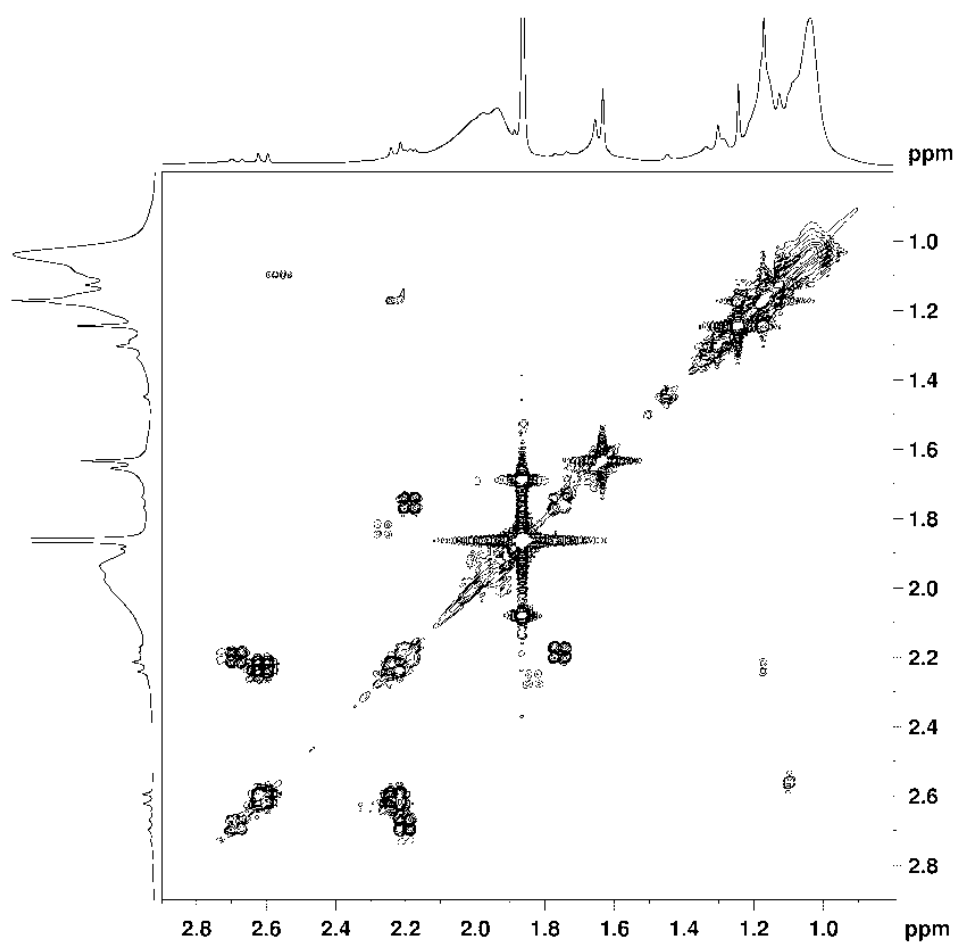

Figure S7. COSY of SARA ATRP mixture. 


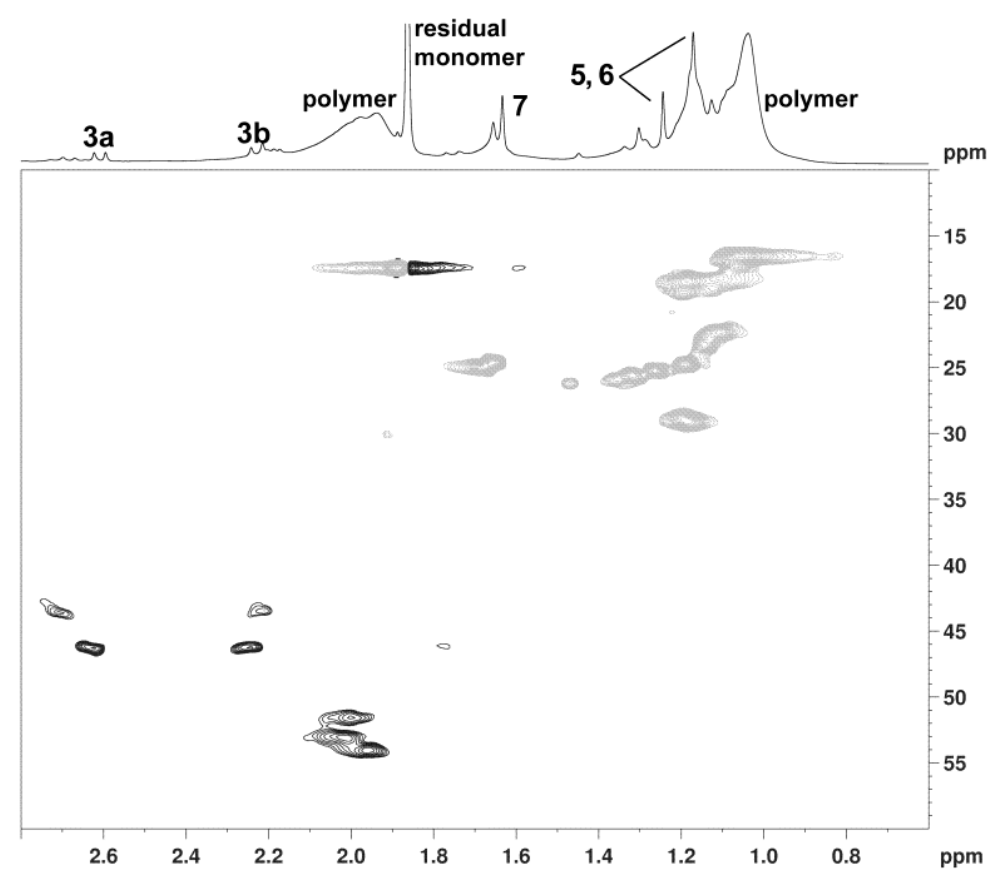

Figure S8. HSQC of SARA ATRP mixture. Relevant atoms are labeled according to Structure A in Scheme S2 (with $\mathrm{R}=\mathrm{H}$ ).
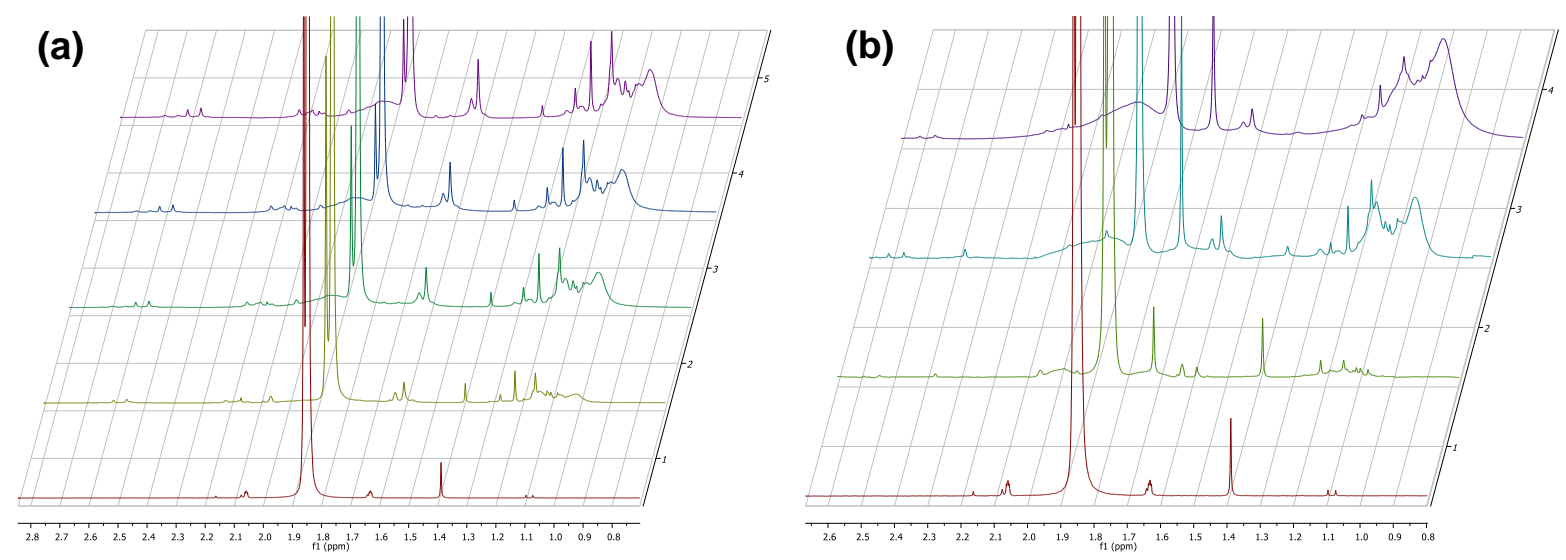

Figure S9. Evolution of NMR spectra with time, for the polymerization of 5\% v/v MAA in $\mathrm{D}_{2} \mathrm{O}$ [MAA]:[RX]:[Cu(OTf $\left.)_{2}\right]:[\mathrm{TPMA}]:[\mathrm{NaX}]=10: 1: 0.001: 0.03: 5$, total $V=5 \mathrm{~mL}, 10 \mathrm{~cm} \mathrm{Cu}$ wire with diameter $d=1 \mathrm{~mm}$. (a) $\mathrm{X}=\mathrm{Br}$; from bottom to top: $0,10,25,55,85 \mathrm{~min}$. (b) $\mathrm{X}=\mathrm{Cl}$; from bottom to top $0,10,25,70 \mathrm{~min}$. 


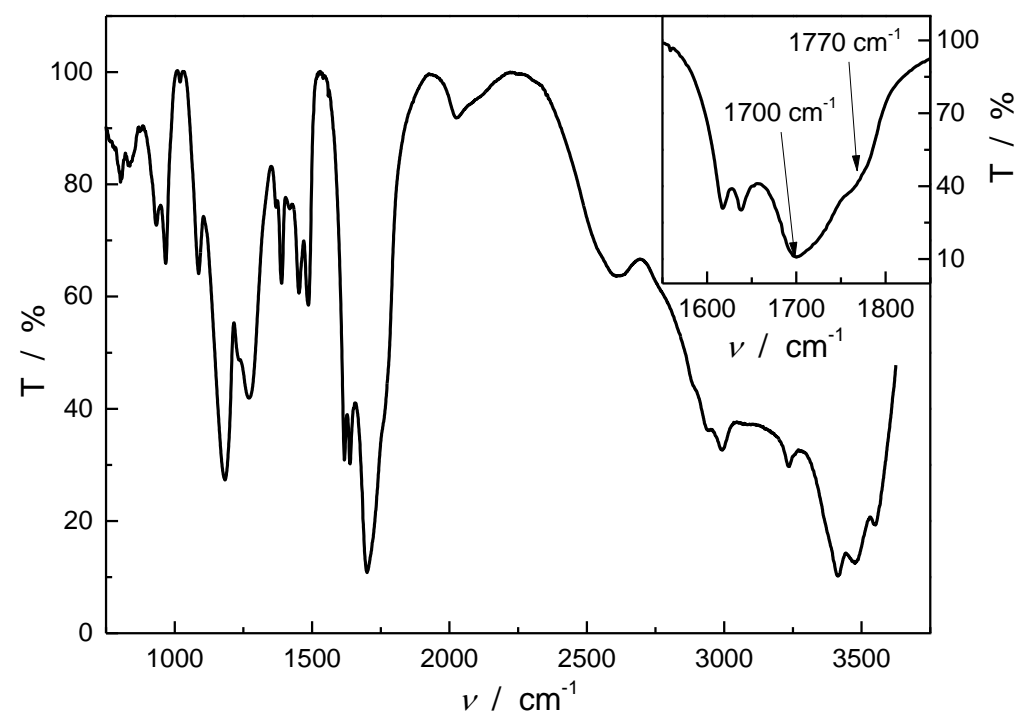

Figure S10. FT-IR of the dried polymerization mixture (under vacuum for $24 \mathrm{~h}$ ). The shoulder at $1770 \mathrm{~cm}^{-1}$ was assigned to the lactone carbonyl stretching. Inset: a zoom on the carbonyl-stretching region of the spectrum.

\section{S3. Electrochemical characterization of Cu/TPMA in the presence of MAA and HCl}

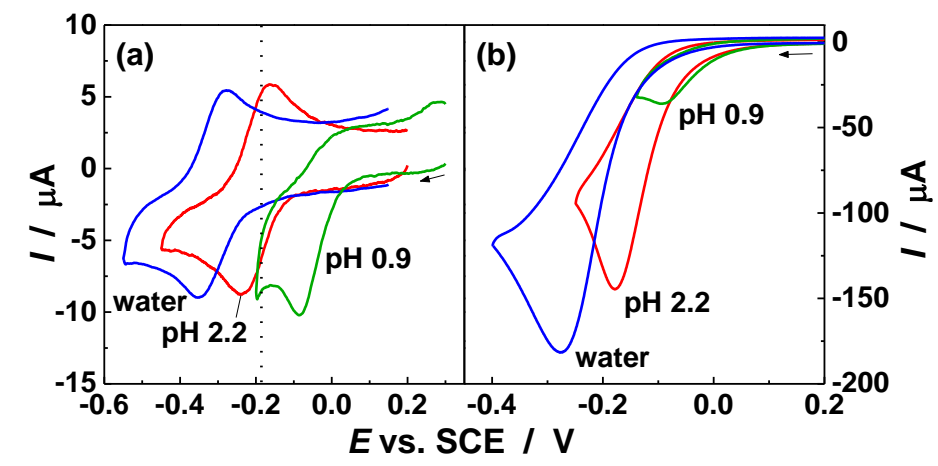

Figure S11. Cyclic voltammetry of $5.9 \times 10^{-4} \mathrm{M}\left[\mathrm{Cu}^{\mathrm{II}} \mathrm{TPMA}\right]^{2+}$ in water (blue), $10 \% \mathrm{v} / \mathrm{v}$ MAA in water (red), and $10 \% \mathrm{v} / \mathrm{v} \mathrm{MAA}$ in water $+0.126 \mathrm{M} \mathrm{HCl}$ (green). CVs were recorded at $0.2 \mathrm{Vs}^{-1}$ in the absence (a) and presence (b) of $5.9 \times 10^{-3} \mathrm{M} \alpha$-bromophenylacetic acid at different $\mathrm{pH}$ values labeled on the curves. $\mathrm{NaCl}$ was added to fix the total concentration of $\mathrm{Cl}^{-}$at $0.3 \mathrm{M}$. The dashed line represents $E_{\text {app }}=-0.18 \mathrm{~V}$ vs. SCE.

The $\mathrm{CV}$ recorded at $\mathrm{pH} 0.9$ was almost completely irreversible (green line in Figure S11a). In this case, $E^{\Theta}$ was estimated as $\left(E_{\mathrm{pc}}+E_{\mathrm{pc} / 2}\right) / 2$, the midpoint between the peak potential, $E_{\mathrm{pc}}$, and the half- 
peak potential, $E_{\mathrm{pc} / 2}$ (the potential at half-peak current). ${ }^{12}$ This is a very rough estimate, as the effect of any chemical reaction following electron transfer to $\mathrm{Cu}^{\mathrm{II}}$ was not taken into account. In fact, the irreversibility of the voltammetric response could be caused by the dissociation of $\left[\mathrm{Cu}^{\mathrm{I}} \mathrm{L}\right]^{+}$ under strong acidic conditions. The stability of $\mathrm{Cu}$-TPMA complexes at low $\mathrm{pH}$ is investigated in more detail in the next section.

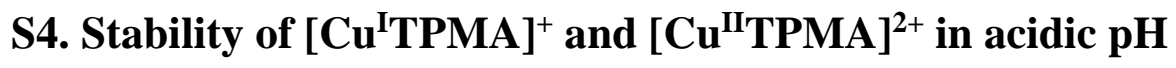

In water, copper ions and TPMA are usually cemented together: the equilibrium constants of reactions S4 and S5 are huge $\left(4 \times 10^{13} \mathrm{M}^{-1}\right.$ and $4 \times 10^{17} \mathrm{M}^{-1}$, respectively). ${ }^{2}$

$$
\begin{array}{ll}
\mathrm{Cu}^{+}+\text {TPMA }=\left[\mathrm{Cu}^{\text {TTPMA }}\right]^{+} & K_{\mathrm{Cu}^{1} \mathrm{~L}} \\
\mathrm{Cu}^{2+}+\text { TPMA }=\left[\mathrm{Cu}^{\mathrm{II} T P M A}\right]^{2+} & K_{\mathrm{Cu}^{\mathrm{I}} \mathrm{L}}
\end{array}
$$

Since the amine ligand is subject to protonation, the conditional formation constants $K_{\mathrm{Cu}^{\mathrm{u}} \mathrm{L}}{ }^{\prime}$ must be considered under acidic conditions:

$$
\begin{gathered}
K_{\mathrm{Cu}^{1} \mathrm{~L}}{ }^{\prime}=\frac{C_{\left[\mathrm{Cu}^{\mathrm{L}} \mathrm{L}^{+}\right.}}{C_{\mathrm{Cu}^{+}} C_{\mathrm{L}}{ }^{\prime}}=K_{\mathrm{Cu}^{\mathrm{I}} \mathrm{L}} \alpha_{\mathrm{L}} \\
K_{\mathrm{Cu}^{\mathrm{u}} \mathrm{L}}{ }^{\prime}=\frac{C_{\mathrm{Cu}^{\mathrm{I}} \mathrm{L}^{2+}}}{C_{\mathrm{Cu}^{2+}} C_{\mathrm{L}}{ }^{\prime}}=K_{\mathrm{Cu}^{\mathrm{I}} \mathrm{L}} \alpha_{\mathrm{L}}
\end{gathered}
$$

where $\alpha_{L}$ represents the fraction of the uncomplexed ligand which is in the unprotonated form and $C_{\mathrm{L}}{ }^{\prime}$ is the total ligand concentration. $\alpha_{\mathrm{L}}$ can be calculated as:

$$
\alpha_{\mathrm{L}}=\frac{1}{1+K_{\mathrm{H} 1}{ }^{\mathrm{m}} a_{\mathrm{H}+}+K_{\mathrm{H} 1}{ }^{\mathrm{m}} K_{\mathrm{H} 2}{ }^{\mathrm{m}}\left(a_{\mathrm{H}+}\right)^{2}+K_{\mathrm{H} 1}{ }^{\mathrm{m}} K_{\mathrm{H} 2}{ }^{\mathrm{m}} K_{\mathrm{H} 3}{ }^{\mathrm{m}}\left(a_{\mathrm{H}+}\right)^{3}+K_{\mathrm{H} 1}{ }^{\mathrm{m}} K_{\mathrm{H} 2}{ }^{\mathrm{m}} K_{\mathrm{H} 3}{ }^{\mathrm{m}} K_{\mathrm{H} 4}{ }^{\mathrm{m}}\left(a_{\mathrm{H}+}\right)^{4}}
$$

where $K_{\mathrm{H} n}{ }^{\mathrm{m}}$ is the protonation constant of each of the four nitrogen atoms in TPMA, and $a_{\mathrm{H}+}$ is the activity of hydronium ions.

Eqs. S6-8 show how $\mathrm{pH}$ affects the stability of $\mathrm{Cu}$-TPMA complexes: the conditional formation constant decreases as $\mathrm{pH}$ is lowered, and therefore the fraction of free copper ions 
increases. Both of these values can be computed as a function of $\mathrm{pH}$ using literature data. ${ }^{2}$ Unfortunately, only an upper limit for $K_{\mathrm{H} 4}{ }^{\mathrm{m}}$ is provided in the literature. This introduces some uncertainty in the values reported in Table $\mathrm{S} 1$ at $\mathrm{pH}$ 0.9. Moreover, the role of $\mathrm{Br}^{-}$or $^{-} \mathrm{Cl}^{-}$was not considered even if halide anions are complexing agent abundant in the polymerization environment. Therefore, considering the effective polymerization conditions, the values reported in Table $\mathrm{S} 1$ are the upper limit of the conditional formation constants (and the lower limit for the amount of free copper ions).

Table S1. Conditional formation constants of $\left[\mathrm{Cu}^{\mathrm{I} / \mathrm{I}} \mathrm{TPMA}\right]^{+/ 2+}$ and fraction of free copper ions at various $\mathbf{p H}$ in water. ${ }^{\mathrm{a}}$

\begin{tabular}{|c|c|c|c|c|c|c|c|}
\hline & \multicolumn{2}{|c|}{ pH 0.9 } & \multicolumn{2}{|c|}{ pH 2.2} & \multicolumn{2}{|c|}{ pH 7} \\
\hline & & $\mathbf{C u}^{\mathrm{I}}$ & $\mathrm{Cu}^{\mathrm{II}}$ & $\mathrm{Cu}^{\mathrm{I}}$ & $\mathrm{Cu}^{\mathrm{II}}$ & $\mathrm{Cu}^{\mathrm{I}}$ & $\mathrm{Cu}^{\mathrm{II}}$ \\
\hline $\log K_{\mathrm{Cu}^{\mathrm{II}} \mathrm{L}}{ }^{\prime}$ & & $2.5 \pm 1.0$ & $5.6 \pm 1.0$ & 6.8 & 10.8 & 13.5 & 17.5 \\
\hline \multirow[t]{2}{*}{ Free $\mathrm{Cu}$ ions } & $\mathrm{L} / \mathrm{Cu}=1$ & $82 \pm 13 \%$ & $2.8 \pm 1.5 \%$ & $1.6 \%$ & $2 \times 10^{-2} \%$ & $7 \times 10^{-4} \%$ & $7 \times 10^{-6 \%}$ \\
\hline & $\mathrm{L} / \mathrm{Cu}=4$ & $56 \pm 26 \%$ & $0.033 \pm 0.032 \%$ & $8 \times 10^{-3} \%$ & $8 \times 10^{-7} \%$ & $2 \times 10^{-9} \%$ & $2 \times 10^{-13} \%$ \\
\hline
\end{tabular}

${ }^{a}$ Calculated from eq. S6 or S7 using literature data: $\left[\mathrm{Cu}{ }^{\mathrm{II}} \mathrm{L}\right]^{2+}$ stability constant and protonation constants were taken from ref. 2 , whereas $[\mathrm{Cu} L]^{+}$stability constant was taken from ref. $3 .{ }^{\mathrm{b}}$ In the case of $K_{\mathrm{H} 4}{ }^{\mathrm{m}}, \log$ $K_{\mathrm{H} 4}{ }^{\mathrm{m}}<2$ was determined in ref. 2 ; the errors were therefore estimated considering that $0<K_{\mathrm{H} 4}{ }^{\mathrm{m}}<10^{2}$. The introduced errors are negligible at $\mathrm{pH} \geq 2.2$.

Two trends clearly emerge from Table S1: TPMA is a weaker ligand at low $\mathrm{pH}$, and $\mathrm{Cu}^{\mathrm{I}}$ is more affected than $\mathrm{Cu}^{\mathrm{II}}$ by the acidic $\mathrm{pH}$ (because the stability constant of $\left[\mathrm{Cu}^{\mathrm{I} T P M A}\right]^{+}$is smaller).

At neutral $\mathrm{pH}$ (ca. 7), both $\left[\mathrm{Cu}^{\mathrm{I} T P M A}\right]^{+}$and $\left[\mathrm{Cu}^{\mathrm{II}} \text { TPMA }\right]^{2+}$ are completely stable. Cyclic voltammetry of $\left[\mathrm{Cu}^{\mathrm{II}} \mathrm{TPMA}\right]^{2+}$ was reversible, which underlined the stability of copper complexes in both oxidation states (Figure S11a). In the presence of initiator, a large catalytic current was observed, further confirming the stability and activity of $\left[\mathrm{Cu}^{\mathrm{I} T P M A}\right]^{+}$(Figure $\mathrm{S} 11 \mathrm{~b}$ ).

At $\mathrm{pH} 2.2$, the $\mathrm{pH}$ of a $10 \%$ v/v MAA solution, TPMA is still able to complex the majority of copper ions. Indeed, changing the $\mathrm{pH}$ from neutral to 2.2 only slightly influenced the shape of the $\left[\mathrm{Cu}^{\mathrm{II}} \mathrm{TPMA}\right]^{2+}$ voltammetric curve. (The shift to more positive potentials was attributed to the more apolar environment induced by the addition of 10\% v/v MAA.) In Figure S11b, a somewhat 
lower catalytic current was recorded. This can be due to a slight dissociation of [Cu'TPMA] ${ }^{+}$ (which lowers its concentration), and to a small decrease of [ $\left.\mathrm{Cu}^{\mathrm{I} T P M A}\right]^{+}$catalytic activity.

Values in Table $\mathrm{S} 1$ show that most of $\mathrm{Cu}^{2+}$ is complexed even at $\mathrm{pH}$ 0.9. Indeed, a well-defined cathodic wave was detected (Figure S11a). On the other hand, $\left[\mathrm{Cu}^{\mathrm{I} T P M A}\right]^{+}$is unstable and a large portion dissociates to $\mathrm{Cu}^{+}+$TPMA. Therefore, the irreversibility of the voltammetric response was caused by $\left[\mathrm{Cu}^{\mathrm{I}} \mathrm{L}\right]^{+}$protonation, followed by dissociation, occurring during the timescale of the CV experiment (few seconds). Nevertheless, a significant current enhancement was recorded in the presence of initiator (Figure $\mathrm{S} 11 \mathrm{~b}$ ), indicating that some $\left[\mathrm{Cu}^{\mathrm{I}} \mathrm{L}\right]^{+}$resisted protonation and activated the $\mathrm{C}-\mathrm{X}$ bond. It is also possible that $\left[\mathrm{Cu}^{\mathrm{I}} \mathrm{L}\right]^{+}$activated the $\mathrm{C}-\mathrm{X}$ bond faster than it dissociated, due to the extremely high activation rate constant of $\mathrm{Cu}^{\mathrm{I}}$ amine complexes in water. ${ }^{13}$ Thus, carrying out the polymerization at $\mathrm{pH} 0.9$ hampered the activity of $\left[\mathrm{Cu}^{\mathrm{I}} \mathrm{TPMA}\right]^{+}$, but did not destroy its ATRP catalytic activity.

The four-fold excess of ligand increased the amount of both $\mathrm{Cu}^{\mathrm{I}}$ and $\mathrm{Cu}^{\mathrm{II}}$ complexes, by shifting equilibria S4 and S5 to the right. Higher catalyst concentration was responsible for the higher polymerization rate and the better control observed when $\mathrm{L} / \mathrm{Cu}=4 / 1$.

\section{S5. GPC traces of PMAA obtained at different pH}
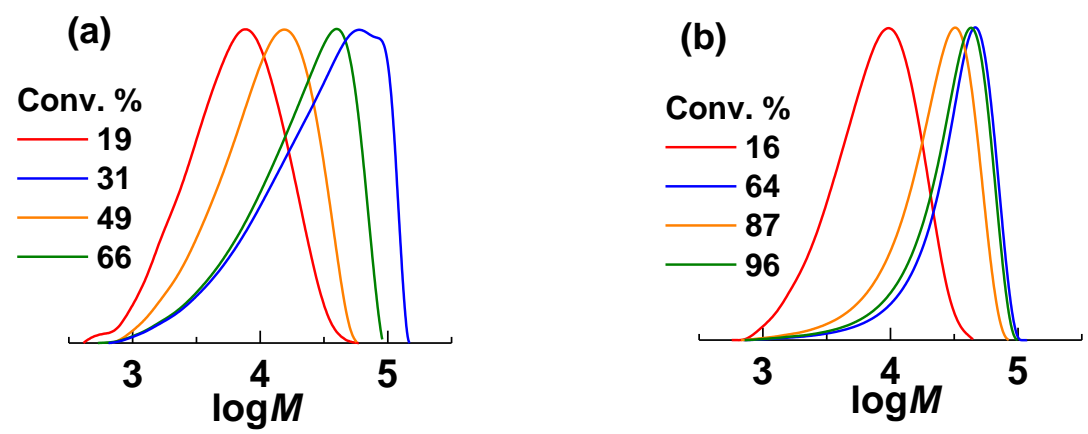

Figure S12. GPC traces for $e$ ATRP of $10 \%$ v/v MAA in $\mathrm{H}_{2} \mathrm{O}$ at $E_{\text {app }}=-0.18 \mathrm{~V}$ vs. SCE, at pH 2.2 (a) and at pH 0.9 (b); $\mathrm{NaCl}$ was added to make $C_{\mathrm{Cl}^{-}}=0.3 \mathrm{M}$. Conditions: $C_{\mathrm{M}}: C_{\mathrm{RX}}: C_{\mathrm{CuCl}_{2}}: C_{\mathrm{TPMA}}=$ 200:1:0.1:0.1, $T=25^{\circ} \mathrm{C}$. 


\section{S6. High molecular weight PMAA}

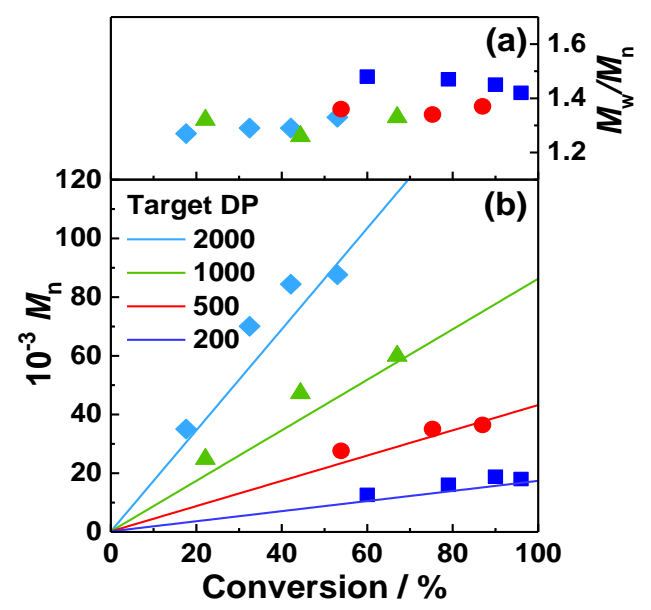

Figure S13. Evolution of molecular-weight distributions (a) and molecular weights (b) as a function of conversion for $e$ ATRP of $10 \% \mathrm{v} / \mathrm{v}$ MAA in $\mathrm{H}_{2} \mathrm{O}$ at $E_{\text {app }}=-0.18 \mathrm{~V}$ vs. SCE at pH 0.9 . Conditions: $C_{\mathrm{M}}: C_{\mathrm{CuCl}_{2}}: C_{\mathrm{TPMA}}: C_{\mathrm{NaCl}}=200: 0.1: 0.4: 29 . C_{\mathrm{Cu}^{2+}}=5.9 \times 10^{-4} \mathrm{M} . C_{\mathrm{BiBA}}$ was changed to target DP from 200 to 2000 . The solid lines represent theoretical $M_{\mathrm{n}}$.

\section{S7. SARA ATRP of MAA}
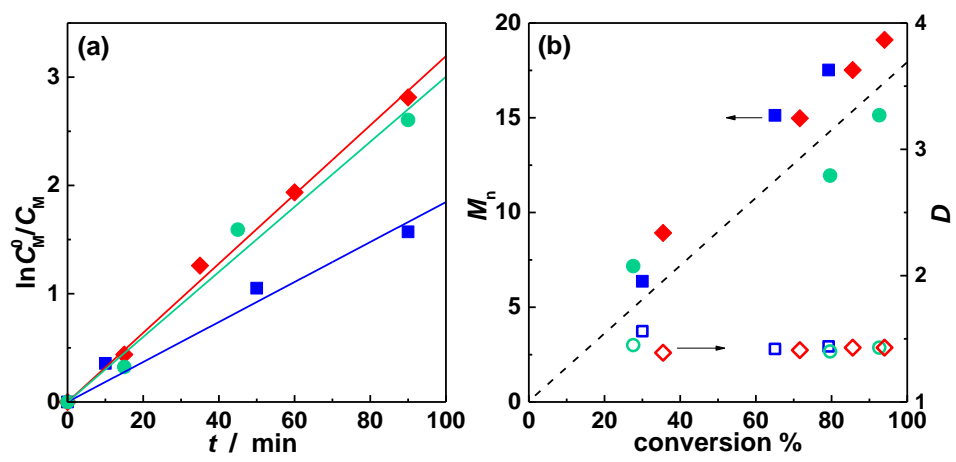

Figure S14. (a) Kinetic plot and (b) evolution of $M_{\mathrm{n}}$ and dispersity with conversion for the ATRP of $10 \% \mathrm{v} / \mathrm{v}$ MAA in water in the presence of $\mathrm{Cu}$ wire. $\mathrm{pH} 0.9$ was set by addition of $\mathrm{HCl}$. Conditions: $C_{\mathrm{M}}: C_{\mathrm{BiBA}}: C_{\mathrm{CuCl}_{2}}: C_{\mathrm{TPMA}}=200: 1: 0.01: 0.4 ; 10 \mathrm{~cm} \mathrm{Cu}$ wire $(d=1 \mathrm{~mm})$. Total $V=5 \mathrm{~mL} . C_{\mathrm{NaCl}}$ $=0.18 \mathrm{M}$ (blue squares); $C_{\mathrm{NaCl}}=0 \mathrm{M}$ (green circles); $C_{\mathrm{CuCl}_{2}}=C_{\mathrm{NaCl}}=0 \mathrm{M}$, in the presence of $\mathrm{Cu}$ wire used in a previous polymerization, which was recycled after simply rinsing with water (red diamonds). 


\section{S8. ATRP of MAA at different monomer concentrations}

The polymerization of MAA under acidic conditions was only slightly affected by varying the monomer concentration in the range $5 \%$ to $25 \% \mathrm{v} / \mathrm{v}$ in water (Table S1). Low MAA content (5\% $\mathrm{v} / \mathrm{v}$ ) could be suitable for the polymerization in the presence of biomolecules that require a highly diluted environment, while higher MAA content $(25 \% \mathrm{v} / \mathrm{v}$, the solubility limit of MAA in water + $\mathrm{HCl}$ ) could be more suitable for a larger scale production of PMAA (Figure S14).

Table S2. SARA ATRP and $e$ ATRP of MAA in Water at Different Concentrations at pH 0.9, $T=25^{\circ} \mathrm{C}^{\mathrm{a}}$

\begin{tabular}{lllllllllll}
\hline Entry & $\begin{array}{l}\% \\
\text { MAA }\end{array}$ & $\begin{array}{l}E_{\text {app }}{ }^{\mathrm{b}} \\
(\mathrm{V})\end{array}$ & $\begin{array}{l}t \\
(\mathrm{~h})\end{array}$ & $\begin{array}{l}Q \\
(\mathrm{C})\end{array}$ & $\begin{array}{l}\text { Conv. } \\
(\%)\end{array}$ & $\begin{array}{l}k_{\mathrm{p}}^{\text {app c }} \\
\left(\mathrm{min}^{-1}\right)\end{array}$ & $M_{\mathrm{n}, \mathrm{th}} \times 10^{-3}$ & $M_{\mathrm{n}, \mathrm{app}} \times 10^{-3}$ & $\mathrm{I}_{\text {eff }}{ }^{\mathrm{d}}$ & $D$ \\
\hline $1^{\mathrm{e}}$ & 5 & - & 1.5 & - & 70 & 0.014 & 12.2 & 14.3 & 0.85 & 1.45 \\
$2^{\mathrm{e}}$ & 10 & - & 1.5 & - & 93 & 0.030 & 16.1 & 15.1 & 1.07 & 1.43 \\
$3^{\mathrm{e}}$ & 25 & - & 1.5 & - & 93 & 0.028 & 16.2 & 18.3 & 0.89 & 1.41 \\
$4^{\mathrm{f}, \mathrm{g}}$ & 10 & -0.18 & 4 & 3.2 & 96 & 0.014 & 16.8 & 18.0 & 0.93 & 1.42 \\
$5^{\mathrm{f,h}}$ & 25 & -0.10 & 1.5 & 3.6 & 53 & 0.007 & 6.5 & 5.6 & 1.17 & 1.42 \\
\hline $\mathrm{a}$
\end{tabular}

${ }^{\mathrm{a}} \mathrm{pH} 0.9$ was set by addition of $\mathrm{HCl} .{ }^{\mathrm{b}}$ vs. SCE. ${ }^{\mathrm{c}}$ The slope of the linear plot of $\ln \left(C_{\mathrm{M}}^{0} / C_{\mathrm{M}}\right)$ vs. $t$. ${ }^{\mathrm{d}} M_{\mathrm{n}, \mathrm{h}} / M_{\mathrm{n}, \mathrm{app} .}{ }^{\mathrm{e}}$ Conditions: $C_{\mathrm{M}}: C_{\mathrm{BiBA}}: C_{\mathrm{CuCl}_{2}}: C_{\mathrm{TPMA}}=200: 1: 0.01: 0.4 .10 \mathrm{~cm} \mathrm{Cu}$ wire $(d=1 \mathrm{~mm})$. Total $V=$ $5 \mathrm{~mL} .{ }^{\mathrm{f}} C_{\mathrm{M}}: C_{\mathrm{RX}}: C_{\mathrm{CuCl}_{2}}: C_{\mathrm{TPMA}}=200: 1: 0.1: 0.1 . C_{\mathrm{Cu}^{2+}}=5.9 \times 10^{-4} \mathrm{M} \cdot{ }^{\mathrm{g}} C_{\mathrm{NaCl}}=0.18 \mathrm{M} \cdot{ }^{\mathrm{h}} C_{\mathrm{NaCl}}=0 \mathrm{M}$.

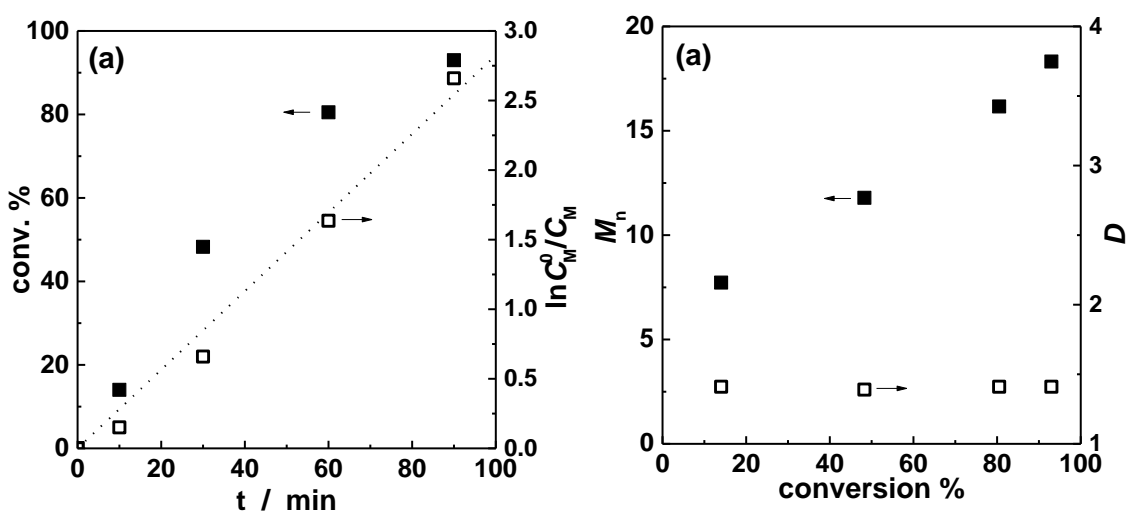

Figure S15. (a) Kinetic plot and (b) evolution of $M_{\mathrm{n}}$ and dispersity with conversion for the ATRP of $25 \% \mathrm{v} / \mathrm{v}$ MAA in water in the presence of $\mathrm{Cu}$ wire. $\mathrm{pH} 0.9$ was set by addition of $\mathrm{HCl}$. Conditions: $C_{\mathrm{M}}: C_{\mathrm{BiBA}}: C_{\mathrm{CuCl}_{2}}: C_{\mathrm{TPMA}}=200: 1: 0.01: 0.4 ; 10 \mathrm{~cm} \mathrm{Cu}$ wire $(d=1 \mathrm{~mm})$. Total $V=5 \mathrm{~mL}$. 


\section{References}

(1) Britovsek, G. J. P.; England, J.; White, A. J. P. Non-heme Iron(II) Complexes Containing Tripodal Tetradentate Nitrogen Ligands and Their Application in Alkane Oxidation Catalysis. Inorg. Chem. 2005, 44, 8125-8134.

(2) Ambundo, E. A.; Deydier, M.-V.; Grall, A. J.; Aguera-Vega, N.; Dressel, L. T.; Cooper, T. H.; Heeg, M. J.; Ochrymowycz, L. A.; Rorabacher, D. B. Influence of Coordination Geometry upon Copper(II/I) Redox Potentials. Physical Parameters for Twelve Copper Tripodal Ligand Complexes. Inorg. Chem. 1999, 38, 4233-4242.

(3) Fantin, M.; Isse, A. A.; Gennaro, A.; Matyjaszewski, K. Understanding the Fundamentals of Aqueous ATRP and Defining Conditions for Better Control. Macromolecules 2015, 48, 68626875.

(4) Lacík, I.; Stach, M.; Kasák, P.; Semak, V.; Uhelská, L.; Chovancová, A.; Reinhold, G.; Kilz, P.; Delaittre, G.; Charleux, B.; Chaduc, I.; D'Agosto, F.; Lansalot, M.; Gaborieau, M.; Castignolles, P.; Gilbert, R. G.; Szablan, Z.; Barner-Kowollik, C.; Hesse, P.; Buback, M. SEC Analysis of Poly(Acrylic Acid) and Poly(Methacrylic Acid). Macromol. Chem. Phys. 2015, 216, 23-37.

(5) Dinoiu, V. Fluorine chemistry: past, present and future. Rev. Roum. Chim. 2006, 51, 11411152.

(6) Tsarevsky, N. V.; Pintauer, T.; Matyjaszewski, K. Deactivation Efficiency and Degree of Control over Polymerization in ATRP in Protic Solvents. Macromolecules 2004, 37, 9768-9778.

(7) Teo, V. L.; Davis, B. J.; Tsarevsky, N. V.; Zetterlund, P. B. Successful Miniemulsion ATRP Using an Anionic Surfactant: Minimization of Deactivator Loss by Addition of a Halide Salt. Macromolecules 2014, 47, 6230-6237.

(8) (a) Matyjaszewski, K. Ranking living systems. Macromolecules 1993, 26, 1787-1788. (b) Matyjaszewski, K. Macromolecules 2012, 45, 4015-4039.

(9) Spectral Database for Organic Compounds (SDBS); ${ }^{13} \mathrm{C}$ NMR spectrum; SDBS No.: 2408; RN 108-29-2; http://sdbs.db.aist.go.jp/sdbs/cgi-bin/direct_frame_disp.cgi?sdbsno=2408 (accessed December 25, 2015).

(10) Destarac, M.; Matyjaszewski, K.; Boutevin, B. Polychloroalkane initiators in coppercatalyzed atom transfer radical polymerization of (meth)acrylates. Macromol. Chem. Phys. 2000, $201,265-272$. 
(11) Spectral Database for Organic Compounds (SDBS); ${ }^{13} \mathrm{C}$ NMR spectrum; SDBS No.: 3859; RN 2052-01-9; http://sdbs.db.aist.go.jp/sdbs/cgi-bin/cre_frame_disp.cgi?sdbsno=3859 (accessed September 10, 2015).

(12) Bard, A. J.; Faulkner, L. R. Electrochemical Methods: Fundamentals and Applications. 2nd ed. ed.; Wiley: Hoboken, NJ, 2000.

(13) Konkolewicz, D.; Krys, P.; Góis, J. R.; Mendonça, P. V.; Zhong, M.; Wang, Y.; Gennaro, A.; Isse, A. A.; Fantin, M.; Matyjaszewski, K. Aqueous RDRP in the Presence of $\mathrm{Cu}^{0}$ : The Exceptional Activity of $\mathrm{Cu}^{\mathrm{I}}$ Confirms the SARA ATRP Mechanism. Macromolecules 2014, 47, $560-570$. 